\title{
Do Operating Profits Induce a Wage Premium Equally Shared among Employees Earning High or Low Incomes?
}

\author{
Jarle Aarstad *(D) and Olav A. Kvitastein
}

check for

updates

Citation: Aarstad, Jarle, and Olav A. Kvitastein. 2021. Do Operating Profits Induce a Wage Premium Equally Shared among Employees Earning High or Low Incomes? Economies 9: 81. https://doi.org/ 10.3390/economies 9020081

Academic Editor:

Joydeep Bhattacharya

Received: 4 February 2021

Accepted: 20 May 2021

Published: 22 May 2021

Publisher's Note: MDPI stays neutral with regard to jurisdictional claims in published maps and institutional affiliations.

Copyright: (c) 2021 by the authors. Licensee MDPI, Basel, Switzerland. This article is an open access article distributed under the terms and conditions of the Creative Commons Attribution (CC BY) license (https:// creativecommons.org/licenses/by/ $4.0 /)$
Mohn Centre for Innovation and Regional Development, Western Norway University of Applied Sciences, P.O. Box 7030, NO-5020 Bergen, Norway; olav.andreas.kvitastein@hvl.no

* Correspondence: jarle.aarstad@hvl.no

Abstract: Panel data show that between 2001 and 2014 Norwegian industries' increasing aggregated operating profits per employee increased average wages and wage inequality. The data imply that increasing profits, perhaps unsurprisingly, induce a wage premium. The data further imply that employees earning high incomes at the outset had the highest wage increase percentage-wise. Decreasing operating profits per employee had opposite but less robust effects on average wages and wage inequality. Panel data Granger causality tests finally showed that average wages, but not wage inequality, reversely and positively affect operating profits per employee.

Keywords: operating profits; Gini-coefficients; average wages; wage inequality; performance; productivity; causality

\section{Introduction}

It is perhaps not far-fetched to assume that increasing operating profits induce a wage premium, as indicated by empirical research (Arai 2003; Arai and Heyman 2009; Blanchflower et al. 1996; Estevao and Tevlin 2003; Knight and Li 2005), but will it be equally shared among employees earning high or low incomes at the outset? In other words, do, for instance, employees earning high incomes at the outset receive a higher wage premium percentage-wise than their colleagues earning lower wages, or is it the other way round? Moreover, assuming that increasing profits induce a wage premium, and percentage-wise, particularly among employees earning high incomes at the outset, will the reverse happen if the operating profits decrease? These are some of the questions we address in this commentary, and, overall, we aim to assess if increasing or decreasing operating profits per employee affects average wages and wage inequality. Using Granger causality tests, we also aim to assess if average wages and wage inequality reversely affect operating profits per employee.

To study our research questions, we analysed a panel dataset of Norwegian industries' aggregated operating profits per full-time employee between 2001 and 2014. In addition, we analysed full-time employees' average wages as an indicator of an eventual wage premium and the Gini coefficients of their distribution as an indicator of wage inequality.

There is an extensive amount of literature discussing the prevalence of wage inequality and what may cause it (e.g., Acemoglu 1998; Akerman et al. 2013; Autor et al. 2008; Bentzen and Tung 2020; Deininger and Squire 1996; Feenstra and Hanson 1996; Heathcote et al. 2010; Hong et al. 2020; Juhn et al. 1993; Kambourov and Manovskii 2009; Kim and Sakamoto 2008; Lemieux 2008; Moretti 2013; Verhoogen 2008), but we have not seen studies explicitly examining if it is a function of profitability in industries. The literature, nonetheless, has addressed the link between firm performance and top management compensation, which taps into the concept of wage inequality (for a seminal contribution, see Beatty and Zajac 1994). Conversely, and in line with the agency argument addressed by Beatty and Zajac (1994), the literature has also discussed if top management compensation increases performance, but empirically this link has been proven weak or absent 
(Jensen and Murphy 1990; Kerr and Bettis 1987). Similar research at a national level has shown that increasing economic inequality decreases national growth and development (Berg et al. 2018; Voitchovsky 2005), but the effect is the opposite if the inequality increases among those with the highest income at the outset (Voitchovsky 2005). The latter finding is in line with studies asserting that technological progress, capital accumulation, and revenues from exports of natural resources propel economic modernisation (Sadik-Zada 2020; Sadik-Zada 2021). Other research has shown that growth at a national level does not reduce inequality, but it reduces poverty at a national level (Deininger and Squire 1996). In addition, a recent study has shown that profitability in the national economy increases wage inequality (Elgin et al. 2020). Finally, we have noted that research indicates a positive link between profitability in the economy and wages earned by the employees (Arai 2003; Arai and Heyman 2009; Blanchflower et al. 1996; Estevao and Tevlin 2003; Knight and Li 2005).

Altogether, research indicates that profitability increases wages and wage inequality (Elgin et al. 2020), but the literature is less consistent concerning the potential effect wage inequality has on growth at a firm or a national level. Responding to this inconsistency, we examined if wage inequality reversely affects profits at an industry level, which we have not seen been done before in previous studies. Likewise, we have not seen previous studies simultaneously illuminate whether increasing or decreasing operating profits affects average wages and wage inequality, i.e., the distribution of wages among employees earning high or low incomes at the outset. Research further indicates that wages stimulate job satisfaction or motivation (e.g., Card et al. 2012), but we do not know if it will further affect operating profits at an industry level, which we examine in this study. Taken together, we argue that our study in its novelty fills important research gaps in the scholarly literature.

\section{Methodology}

To study our research questions, we constructed a panel dataset using Norwegian employee-level data linked with enterprise- and industry-level data. The unit of analysis was industry $i$ (digit-two NACE code) at year $t(t=2001-2014){ }^{1}$

To estimate wage inequality in industry $i$ at year $t$, we used the Gini coefficient of wages earned by full-time employees. According to Statistics Norway, wages include salaries, fees, other allowances, sickness benefits, maternity, and adoption benefits. It was important to include eventual sickness benefits, maternity, and adoption benefits as they are compensations received when an employee cannot work (if not included, wages in certain industries would be artificially affected by relatively high or low work absentee).

Criteria for inclusion of wages in the calculation were that an employee was reported with positive income in year $t$ and was a full-time employee in the same enterprise at year $t$ and $t_{-1}$. We studied average wages in industry $i$ at year $t$ by using the same data of full-time employees. For each year, we divided nominal wages on Statistics Norway's wage index (2001 set to 1).

To estimate industry $i$ 's aggregated operating profits per full-time employees at year $t$, we first summarised the operating profits for each enterprise in the industry at year $t$. Afterward, we divided the summarised operating profits by the sum of full-time employees in the industry at year $t$ and finally divided it by the consumer price inflator from Statistics Norway (2001 set to 1). Criteria for an enterprise to be included in the calculation were that in year $t$ it had positive operating revenues and had data on operating profits (positive or negative).

As operating profits per employee, ceteris paribus, increase if employment decreases, and vice versa, we included employment as a control variable. To estimate employment in industry $i$ at year $t$, we first used the number of full-time employees at year $t$ and divided the measure by the average number of full-time employees for all time periods the industry was included in the data. The reason for the division was to account for large differences in employment across industries.

To avoid the inclusion of very small industries in the panel, which may have induced relatively strong fluctuations and extreme values, for instance, due to mergers and ac- 
quisitions within and between industries, we included industries at year $t$ with at least 1000 full-time employees and 100 enterprises. Criteria for an enterprise to be counted were that in year $t$ it had positive operating revenues and reported operating profits (positive or negative).

\section{Results}

We analysed the panel in Stata 15. To enable comparisons between the dependent variables, we log-transformed them by using the natural logarithm. In all models, we included year dummies as controls.

Table 1 reports estimates using industry-fixed effects regressions with robust standard errors that account for potential within-industry autocorrelation and heteroscedasticity. Model 1A showed that increasing operating profits per employee (operating profits per employee at $t>$ operating profits per employee at $t_{-1}$ ) significantly increased average wages. This implies that increasing profits per employee, perhaps unsurprisingly, results in a wage premium. The significant positive regressor in Model 1B further showed that decreasing profits (operating profits per employee at $t<$ operating profits per employee at $t_{-1}$ ) significantly decreased average wages, but the effect was less marked and robust as compared to Model 1A.

Models 2A and 2B replicated the two first models, except for modelling a time lag of one year $\left(t_{-1}\right)$ between the independent variable plus employment as a control variable and the dependent variable. Statistically, no conclusion was altered except that the effect of operating profits on average wages abated in magnitude and robustness with a time lag of one year.

Models $3 \mathrm{~A}$ to $4 \mathrm{~B}$ in Table 1 replicated the first four models, except that the dependent variable was now wage inequality instead of average wages. Increasing operating profits per employee had very similar effects on wage inequality (Models $3 \mathrm{~A}$ and $4 \mathrm{~A}$ ) as they had on average wages (Models 1A and 2A). This implies that increasing profits per employee not only results in a wage premium but that employees earning high incomes at the outset also receive the highest wage increase percentage-wise.

Models 3B and 4B in Table 1 further showed that decreasing operating profits decreased wage inequality, but the effects were less marked and robust than in Models 3A and $4 \mathrm{~A}$. Employment as a control variable had non-significant effects on the dependent variables in all models.

Having shown that average wages and wage inequality are a function of operating profits per employee, we cannot rule out potential reverse causalities. To address this issue, we first balanced the panel (Yujun 2009), which implies a drop from a total of 853 observations to 798, and next carried out panel data Granger causality tests using the Bayesian information criterion on the number of lags included (see Dumitrescu and Hurlin 2012; Lopez and Weber 2017). ${ }^{2}$ Table 2 shows that average wages were a function of operating profits per employee (1), and vice versa (2). In other words, operating profits increased average wages, and average wages also increased operating profits. Table 2 further shows that wage inequality was a function of operating profits per employee (3), but not vice versa (4). In other words, operating profits increased wage inequality, but wage inequality did not increase operating profits. We summarise our empirical findings in Figure 1. 
Table 1. Fixed effects regressions with robust standard errors.

\begin{tabular}{|c|c|c|c|c|c|c|c|c|}
\hline \multirow{2}{*}{$\begin{array}{l}\text { Dep. Var. } \\
\text { Model }\end{array}$} & \multicolumn{4}{|c|}{ Average Wages at $t(\log )$} & \multicolumn{4}{|c|}{ Wage Inequality at $t(\log )$} \\
\hline & $1 \mathrm{~A}$ & 1B & $2 \mathrm{~A}$ & 2B & $3 \mathrm{~A}$ & 3B & $4 \mathrm{~A}$ & $4 \mathrm{~B}$ \\
\hline Operating profits per employee at $t$ & $\begin{array}{l}6.29 \times 10^{-5 * * *} \\
\left(1.03 \times 10^{-5}\right)\end{array}$ & $\begin{array}{l}4.82 \times 10^{-5 * *} \\
\left(1.70 \times 10^{-5}\right)\end{array}$ & & & $\begin{array}{l}6.14 \times 10^{-5 * * *} \\
\left(1.60 \times 10^{-5}\right)\end{array}$ & $\begin{array}{l}3.24 \times 10^{-5}+ \\
\left(1.89 \times 10^{-5}\right)\end{array}$ & & \\
\hline Employment at $t$ & 0.029 & 0.029 & & & -0.051 & -0.051 & & \\
\hline & $(0.022)$ & $(0.027)$ & & & $(0.059)$ & $(0.052)$ & & \\
\hline $\begin{array}{l}\text { Operating profits growth (operating } \\
\text { profits at } t>\text { operating profits at } t_{-1} \text { ) }\end{array}$ & $\sqrt{ }$ & & & & $\sqrt{ }$ & & & \\
\hline $\begin{array}{l}\text { Operating profits reduction (operating } \\
\text { profits at } t<\text { operating profits at } t_{-1} \text { ) }\end{array}$ & & $\sqrt{ }$ & & & & $\sqrt{ }$ & & \\
\hline Operating profits per employee at $t_{-1}$ & & & $\begin{array}{l}3.94 \times 10^{-5 * *} \\
\left(1.34 \times 10^{-5}\right)\end{array}$ & $\begin{array}{l}3.76 \times 10^{-5 *} \\
\left(1.74 \times 10^{-5}\right)\end{array}$ & & & $\begin{array}{l}4.14 \times 10^{-5 * *} \\
\left(1.46 \times 10^{-5}\right)\end{array}$ & $\begin{array}{l}4.10 \times 10^{-5 *} \\
\left(1.99 \times 10^{-5}\right)\end{array}$ \\
\hline Employment at $t_{-1}$ & & & $\begin{array}{l}0.032 \\
(0.024)\end{array}$ & $\begin{array}{l}0.042 \\
(0.034)\end{array}$ & & & $\begin{array}{l}-0.052 \\
(0.061)\end{array}$ & $\begin{array}{l}-0.007 \\
(0.056)\end{array}$ \\
\hline $\begin{array}{l}\text { Operating profits growth (operating } \\
\text { profits at } t_{-1}>\text { operating profits at } t_{-2} \text { ) }\end{array}$ & & & $\sqrt{ }$ & & & & $\sqrt{ }$ & \\
\hline $\begin{array}{l}\text { Operating profits growth (operating } \\
\text { profits at } t_{-1}<\text { operating profits at } t_{-2} \text { ) }\end{array}$ & & & & $\sqrt{ }$ & & & & $\sqrt{ }$ \\
\hline Year dummies included (but not reported) & $\sqrt{ }$ & $\checkmark$ & $\checkmark$ & $\sqrt{ }$ & $\checkmark$ & $\sqrt{ }$ & $\checkmark$ & $\checkmark$ \\
\hline Nobs./groups & $447 / 65$ & $406 / 67$ & $411 / 63$ & $372 / 67$ & $447 / 65$ & $406 / 67$ & $411 / 63$ & $372 / 67$ \\
\hline Min./avg./max. obs. per group & $1 / 6.9 / 11$ & $2 / 6.1 / 9$ & $1 / 6.5 / 10$ & $1 / 5.6 / 9$ & $1 / 6.9 / 11$ & $2 / 6.1 / 9$ & $1 / 6.5 / 10$ & $1 / 5.6 / 9$ \\
\hline F-value & $20.6 * * *$ & $8.85^{* * *}$ & $7.85^{* * *}$ & $6.79 * * *$ & $13.4^{* * *}$ & $10.1 * * *$ & $10.6^{* * *}$ & $13.7^{* * *}$ \\
\hline
\end{tabular}


Table 2. Panel data Granger causality tests.

\begin{tabular}{ccc}
\hline & \multicolumn{2}{c}{ Operating Profits per Employee } \\
\cline { 2 - 3 } & Independent Variable & Dependent Variable \\
\hline \multirow{3}{*}{ Average wages (AW) } & (1) AW as dependent variable & (2) AW as independent variable \\
& Z-bar $=8.21(p<0.001)$ & Z-bar $=8.31(p<0.001)$ \\
& Z-bar tilde $=4.49(p<0.001)$ & Z-bar tilde $=4.56(p<0.001)$ \\
\hline \multirow{2}{*}{ Wage inequality (WI) } & (3) WI as dependent variable & (4) WI as independent variable \\
& Z-bar $=13.9(p<0.001)$ & Z-bar $=-0.214(p=0.831)$ \\
& Z-bar tilde $=8.18(p<0.001)$ & Z-bar tilde $=-1.01(p=0.312)$ \\
\hline
\end{tabular}

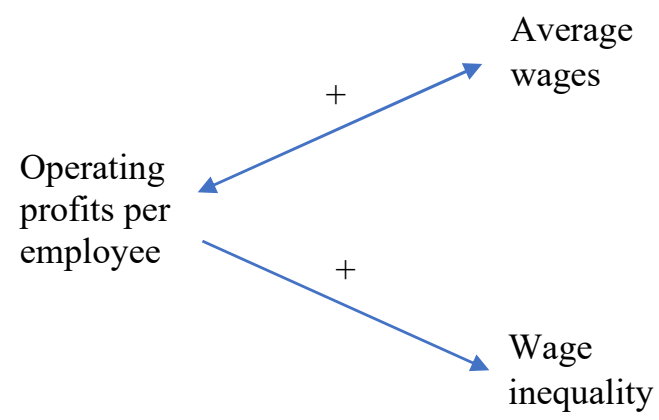

Figure 1. An empirical model.

To identify potential cross-sectional dependence, we applied Freess' (1995) tests (De Hoyos and Sarafidis 2006), which strongly rejected the assumption. For the tests, we used the balanced panel and, based on the models identifying each dependent variable, excluded as constraints increasing or decreasing values of the independent variables. ${ }^{3}$

\section{Conclusions}

Panel data analyses showed that Norwegian industries' aggregated operating profits per employee positively affected average wages, which is in line with previous research (Arai 2003; Arai and Heyman 2009; Blanchflower et al. 1996; Estevao and Tevlin 2003; Knight and Li 2005). The analyses furthermore showed that employees earning high incomes at the outset had the highest wage increase percentage-wise, and a similar finding had recently been shown in another study at a national level (Elgin et al. 2020). A novelty in this study was that it also showed that decreasing operating profits had opposite but less robust effects on average wages and wage inequality. Another novelty was that it showed that average wages reversely have a positive effect on profitability. A potential explanation is that wages affect job satisfaction or motivation, as shown in other research (e.g., Card et al. 2012), which, in turn, affects profits. Finally, the study did not show that wage inequality reversely affected profitability at an industry level, which is in line with seminal firm-level research indicating that top management compensation does not consistently increase performance (Jensen and Murphy 1990; Kerr and Bettis 1987). In a similar vein, research at a national level had shown that wage inequality has mixed effects on economic growth (Berg et al. 2018; Voitchovsky 2005).

Operating profits per employee are likely to vary across firms in the same industry. It may explain why wage inequality is a function of industries' aggregated operating profits per employee. However, the tentative explanation hinges on the assumption that a change in operating profits largely occurs in firms having high operating profits per employee at the outset and is arguably a topic for future research.

Finding that operating profits both affect average wages and wage inequality does not necessarily imply that an industry's change in average wages (wage inequality) explains or mediates a change in wage inequality (average wages). Theoretically speaking, we can instead assume that a change in average wages occurs in specific industries only, while a change in wage inequality occurs in other industries only. To address these issues, we 
had in unreported models included wage inequality as a mediating variable when average wages was a dependent variable, and vice versa, but without substantially altering any statistical conclusion concerning operating profits as an independent variable. The absent mediating effects may indicate that a change in average wages and wage inequality occur in different industries, as speculated above. However, other unreported analyses carrying out panel data Granger causality tests showed that a change in average wages induced a change in wage inequality, and vice versa. Therefore, we assume a partial industry overlap concerning changes in average wages and wage inequality, and future research should further investigate this issue. Finding that average wages cause a change in wage inequality, and vice versa, are furthermore in contrast to Bentzen and Tung (2020), showing no causal associations between similar concepts at a national level in a developing economy of Vietnam.

Finding that average wages, but not wage inequality, reversely and positively affect operating profits per employee is a final topic to further examine in future research. In line with research by, for instance, Card et al. (2012), we speculate that average wages stimulating employees' motivation is one reason as to why they affect operating profits. However, there may also be other alternative explanations that scholars should examine in future research.

Author Contributions: Conceptualization, J.A.; methodology, J.A. and O.A.K.; formal analysis, J.A. and O.A.K.; writing—original draft preparation, J.A.; writing — review and editing, J.A. and O.A.K. All authors have read and agreed to the published version of the manuscript.

Funding: There was no external funding for this research.

Data Availability Statement: The data are not publicly available due to restrictions imposed by their provider.

Conflicts of Interest: The authors declare no conflict of interest.

\section{Notes}

1 The NACE codes were updated in 2002 and 2007. At the outset, we consistently used each firm's code the first year it appeared in the data for all later years included, except for when it had a later updated code, which we then used instead (for all later years included). For firms where we had data both before and after 2007, we used the NACE codes as of 2007. For firms included in the data in 2001 only, we first converted the old codes (from 1994) to the updated codes from 2002 by using a conversion key from Statistics Norway. If an old code (from 1994) had more than one corresponding code as of 2002, through inspection of the description of each industry, we included the code from 2002 that resembled the closest similarity with the old code. Finally, we converted the 2002 codes of firms included in the data before 2007 only (including those converted from the codes from 1994) with the codes from 2007 by using another conversion key from Statistics Norway.

2 The test is impossible if the panel is very unbalanced.

3 The test is impossible if the panel is very unbalanced (if the data are balanced at the outset, in most cases, it will become unbalanced when including constraints concerning increasing or decreasing values of the independent variables). Our approach, nonetheless, assessed if there is cross-sectional dependence in the panel concerning the variables we examined in each model.

\section{References}

Acemoglu, Daron. 1998. Why do new technologies complement skills? Directed technical change and wage inequality. Quarterly Journal of Economics 113: 1055-89. [CrossRef]

Akerman, Anders, Elhanan Helpman, Oleg Itskhoki, Marc-Andreas Muendler, and Stephen Redding. 2013. Sources of wage inequality. American Economic Review 103: 214-19. [CrossRef]

Arai, Mahmood. 2003. Wages, profits, and capital intensity: Evidence from matched worker-firm data. Journal of Labor Economics 21: 593-618. [CrossRef]

Arai, Mahmood, and Fredrik Heyman. 2009. Microdata evidence on rent-sharing. Applied Economics 41: 2965-76. [CrossRef]

Autor, David H., Lawrence F. Katz, and Melissa S. Kearney. 2008. Trends in US wage inequality: Revising the revisionists. Review of Economics and Statistics 90: 300-23. [CrossRef] 
Beatty, Randolph P., and Edward J. Zajac. 1994. Managerial incentives, monitoring, and risk bearing: A study of executive compensation, ownership, and board structure in initial public offerings. Administrative Science Quarterly 39: 313-35. [CrossRef]

Bentzen, Jan, and Le Thanh Tung. 2020. A causality test between income, inequality and poverty-Empirical evidence from South-East Asia. Applied Economics Letters, 1-4. [CrossRef]

Berg, Andrew, Jonathan D. Ostry, Charalambos G. Tsangarides, and Yorbol Yakhshilikov. 2018. Redistribution, inequality, and growth: New evidence. Journal of Economic Growth 23: 259-305. [CrossRef]

Blanchflower, David G., Andrew J. Oswald, and Peter Sanfey. 1996. Wages, profits, and rent-sharing. Quarterly Journal of Economics 111: 227-51. [CrossRef]

Card, David, Alexandre Mas, Enrico Moretti, and Emmanuel Saez. 2012. Inequality at Work: The Effect of Peer Salaries on Job Satisfaction. American Economic Review 102: 2981-3003. [CrossRef]

De Hoyos, Rafael E., and Vasilis Sarafidis. 2006. Testing for Cross-Sectional Dependence in Panel-Data Models. The Stata Journal 6: 482-96. [CrossRef]

Deininger, Klaus, and Lyn Squire. 1996. A new data set measuring income inequality. World Bank Economic Review 10: 565-91. [CrossRef]

Dumitrescu, Elena-Ivona, and Christophe Hurlin. 2012. Testing for Granger non-causality in heterogeneous panels. Economic Modelling 29: 1450-60. [CrossRef]

Elgin, Ceyhun, Adem Yavuz Elveren, and Joseph Bourgeois. 2020. Informality, Inequality and Profit Rate. Applied Economics Letters, 1-4. [CrossRef]

Estevao, Marcello, and Stacey Tevlin. 2003. Do firms share their success with workers? The response of wages to product market conditions. Economica 70: 597-617. [CrossRef]

Feenstra, Robert C., and Gordon H. Hanson. 1996. Globalization, outsourcing, and wage inequality. American Economic Review 86: 240-45.

Frees, Edward W. 1995. Assessing cross-sectional correlation in panel data. Journal of Econometrics 69: 393-414. [CrossRef]

Heathcote, Jonathan, Kjetil Storesletten, and Giovanni L. Violante. 2010. The macroeconomic implications of rising wage inequality in the United States. Journal of Political Economy 118: 681-722. [CrossRef]

Hong, Soondong, Heejoon Han, and Chang Sik Kim. 2020. World distribution of income for 1970-2010: Dramatic reduction in world income inequality during the 2000s. Empirical Economics 59: 765-98. [CrossRef]

Jensen, Michael C., and Kevin J. Murphy. 1990. Performance pay and top management incentives. Journal of Political Economy 98: 225-64. [CrossRef]

Juhn, Chinhui, Kevin M. Murphy, and Brooks Pierce. 1993. Wage inequality and the rise in returns to skill. Journal of Political Economy 101: 410-42. [CrossRef]

Kambourov, Gueorgui, and Iourii Manovskii. 2009. Occupational mobility and wage inequality. The Review of Economic Studies 76: 731-59. [CrossRef]

Kerr, Jeffrey, and Richard A. Bettis. 1987. Boards of directors, top management compensation, and shareholder returns. Academy of Management Journal 30: 645-64.

Kim, ChangHwan, and Arthur Sakamoto. 2008. The rise of intra-occupational wage inequality in the United States, 1983 to 2002. American Sociological Review 73: 129-57. [CrossRef]

Knight, John, and Shi Li. 2005. Wages, firm profitability and labor market segmentation in urban China. China Economic Review 16: 205-28. [CrossRef]

Lemieux, Thomas. 2008. The changing nature of wage inequality. Journal of population Economics 21: 21-48. [CrossRef]

Lopez, Luciano, and Sylvain Weber. 2017. Testing for Granger Causality in Panel Data. The Stata Journal 17: 972-84. [CrossRef]

Moretti, Enrico. 2013. Real wage inequality. American Economic Journal: Applied Economics 5: 65-103. [CrossRef]

Sadik-Zada, Elkhan Richard. 2020. Distributional Bargaining and the Speed of Structural Change in the Petroleum Exporting Labor Surplus Economies. The European Journal of Development Research 32: 51-98. [CrossRef]

Sadik-Zada, Elkhan Richard. 2021. Natural resources, technological progress, and economic modernization. Review of Development Economics 25: 381-404. [CrossRef]

Verhoogen, Eric A. 2008. Trade, quality upgrading, and wage inequality in the Mexican manufacturing sector. Quarterly Journal of Economics 123: 489-530. [CrossRef]

Voitchovsky, Sarah. 2005. Does the profile of income inequality matter for economic growth? Journal of Economic Growth 10: 273-96. [CrossRef]

Yujun, Lian. 2009. XTBALANCE: Stata Module to Transform the Dataset into Balanced Panel Data. Statistical Software Components S457094. Boston: Boston College. 